\title{
TEORI BEBAN KOGNITIF: ELEMEN INTERAKTIVITAS DALAM PEMBELAJARAN MATEMATIKA
}

\author{
Barep Yohanes $^{\mathrm{a}}$,Rendi Lusbiantoro ${ }^{\mathrm{b}}$ \\ ${ }^{a}$ Program Studi Pendidikan Matematika FMIPA UNIBA \\ Jl. Ikan Tongkol No.01 Kertosari - Banyuwangi 68416, barepyohanes@gmail.com \\ ${ }^{\mathrm{b}} \mathrm{SMK}$ TELKOM Malang \\ Jl. Danau Ranau Sawojajar Malang 65139, rendy@smktelkom-mlg.sch.id
}

\begin{abstract}
Abstrak
Penelitian ini bertujuan untuk mendeskripsikan munculnya Elemen Interaktivitas pada beban kognitifintrinsik siswa dalam pembelajaran matematika. Pendekatan dalam penelitian ini adalah pendekatan kualitatif dan jenis penelitian ini adalah penelitian deskriptif. Data yang diperoleh dalam penelitian ini meliputi data kualitatif yang diperoleh dari lembar observasi, jurnal belajar siswa, wawancara, dan rekaman video. Untuk pengecekan keabsahan data menggunakan metode triangulasi dan strategi menyajikan informasi yang berbeda atau negatif. Subjek dalam penelitian ini adalah siswa kelas X RPL 3 SMK TELKOM Malang. Hasil penelitian yang diperoleh bahwa Elemen Interaktivitas merupakan bagian dari Beban kognitif intrinsic yang muncul dalam pembelajaran.Elemen Interaktivitas yang muncul dalam pembelajaran dapat terlihat dari kompleksitas materi yang sedang dipelajari sehingga siswa harus menghubungkan antara topik materi kedudukan titik, garis, bidang dan topik materi jarak dan besar sudut dalam bangun ruang. Kompleksitas materi yang sedang dipelajari juga melibatkan materi prasyarat seperti kesebangunan dua segitiga, aljabar, sudut istimewa dan keahlian siswa dalam belajar matematika. Saran yang dapat diberikan dari peneliti bahwa dalam belajar perlu memperhatikan elemen interaktivitas untuk mengetahui beban yang diemban oleh kognitif siswa. Guru harus selalu mengevaluasi kemampuan siswa sehingga siswa tidak terlalu berat dalam belajar.
\end{abstract}

Kata Kunci: beban kognitif, elemen interaktivitas, pembelajaran matematika

\begin{abstract}
This study aims to describe the emergence of Elements of Interactivity on the intrinsic cognitive load of students in mathematics learning. The approach in this study is a qualitative approach and this type of research is descriptive research. Data obtained in this study include qualitative data obtained from observation sheets, student learning journals, interviews, and video recordings. To check the validity of the data using the triangulation method and the strategy presents different or negative information. The subjects in this study were students of class X RPL 3 of TELKOM Vocational School Malang. The results of the study obtained that the Element of Interactivity is part of the intrinsic cognitive load that arises in learning. Interactivity elements that appear in learning can be seen from the complexity of the material being studied so that students must connect between material topics where the points, lines, fields and topics of material distance and the angles in building space. The complexity of the material being studied also involves prerequisite material such as the congruence of two triangles, algebra, special angles and the students' expertise in learning mathematics. Suggestions can be given from the researcher that in learning it is necessary to pay attention to the element of interactivity to find out the burden carried out by the cognitive students. The teacher must always evaluate students' abilities so that students are not too heavy in learning.
\end{abstract}

Keywords: cognitive load, elements of interactivity, mathematic learning 


\section{PENDAHULUAN}

Pembelajaran merupakan proses interaksi yang terjadi antara elemenelemen yang terdiri dari guru, siswa, dan sumber belajar pada lingkungan belajar (permendikbud, no. 103, 2014). Kolaborasi berkesinambungan antar elemen-elemen tersebut diharapkan akan membentuk suatu keadaan lingkungan belajar yang ideal. Siswa tidak akan maksimal jika tidak ada guru dalam kegiatan pembelajaran. Begitu juga guru tanpa suatu sumber belajar akan mengalami kesulitan dalam penyampaian materi dan kurang maksimal dalam pembelajaran. Ketiga elemen tersebut harus saling melengkapi dan saling membutuhkan guna mencapai suatu tujuan pembelajaran yang diharapkan.

Guru memiliki peran yang sangat penting dalam kegiatan pembelajaran. Guru memiliki wewenang dalam kegiatan yang dilakukan siswa pada saat kegiatan pembelajaran. Guru harus memberi fasilitas kepada siswa untuk dapat menyampaikan pendapat dan juga gagasan dalam kegiatan pembelajaran (Subanji, 2015:1). Guru memberikan kesempatan untuk siswa dapat menyamapaikan pendapatnya ataupun pemahaman yang dimilikinya.

Belajar merupakan kegiatan utama dalam suatu kegiatan pembelajaran. Belajar adalah suatu aktivitas atau suatu proses untuk memperoleh pengetahuan, meningkatkan keterampilan, memperbaiki perilaku, sikap, dan mengokohkan kepribadian (Suyono dan Hariyanto, 2016:9). Belajar dapat menggali pengetahuan tentang suatu topik atau teori yang berkembang.Teori yang telah dimiliki juga dapat dipertajam dengan latihanlatihan yang lebih mendalam sehingga dapat meningkatkan keterampilan yang dimiliki.Melalui belajar dapat membantu untuk memperbaiki perilaku secara social ataupun perilaku secara prosedural dalam bertindak. Belajar akan membawa suatu perubahan yang nyata pada siswa.

Belajar juga merupakan kegiatan mental yang dilakukan oleh siswa untuk memahami suatu pengetahuan.Siswa memerlukan kemampuan mental atau pikiran saat mereka melakukan kegiatan belajar (Slavin, 2009, dan Cooper, 1998).Kemampuan mental atau pikiran ini berhubungan dengan perkembangan kognitif siswa yang dimiliki untuk belajar. Dalam kegiatan belajar siswa akan menggunakan kemampuan yang ada pada kognitif mereka. Semakin siswa sering melakukan kegiatan belajar akan membuat siswa semakin memiliki perkembangan kognitif yang baik pula.

Pemrosesan informasi merupakan aktivitas yang dilakukan oleh otak dalam memproses informasi baru dan 
menyimpannya, kemudian memunculkan kembali informasi tersebut apabila dibutuhkan (Winkel, 2005:120, dan Slavin, 2009:216). Informasi yang diperoleh oleh siswa akan diproses dalam otaknya atau diabaikan begitu saja. Informasi juga akan dihubungkan dengan informasi lain yang telah dimiliki sehingga akan membentuk suatu pengetahuan yang saling berkesinambungan antara informasi yang diperoleh dengan informasi yang dimiliki.

Memori kerja merupakan pusat dari pemrosesan suatu informasi yang telah diterima oleh seorang siswa.Upaya yang dilakukan seorang siswa untuk memproses suatu informasi akan memberikan beban pada sistem memori siswa. Beban yang terjadi pada memori kerja inilah yang disebut beban kognitif (Plass, Moreno, dan Brunken, 2010, dan Sweller, Ayres, dan Kalyuga, 2011).Beban kognitif mengarah pada kapasitas memori kerja yang terbatas dan tak terbatasnya memori jangka panjang.Semakin berat memori kerja melakukan suatu tugas maka semakin berat pula beban kognitif yang diterima oleh siswa.Beban kognitif terjadi ketika siswa berada pada situasi memproses informasi atau memahami suatu materi.

Beban kognitif yang diterima oleh seseorang ditentukan oleh unsur/elemen interaktivitas

dalam

suatu

informasi.Elemen interaktivitas adalah element yang harus diproses secara bersamaan dalam memori kerja karena mereka secara logis berkaitan.Sedangkan elemen adalah segala sesuatu yang harus dipelajari atau diproses, atau yang telah dipelajari atau diproses.Elemen-elemen yang ada dalam suatu informasi inilah yang mempengaruhi besar kecilnya beban kognitif seseorang. Bila dalam suatu informasi memiliki elemen yang sangat banyak, memori kerja juga akan semakin berat memproses informasi dan mengakibatkan beban kognitif semakin besar.

Beban Kognitif Intrinsic mengacu pada jumlah elemen yang harus diproses secara bersamaan dalam memori kerja untuk mengkonstruksi skema atau disebut dengan elemen interaktivitas. Element interaktifitas tergantung pada dua hal yaitu: kerumitan materi dalam belajar dan juga keahlian peserta didik dalam belajar (ketersediaan skema dan automatisasi) (Artino, 2008:428). Sehingga beban kognitif Intrinsicmelalui elemen interaktivitas ditentukan oleh interaksi antara sifat bahan yang dipelajari dan keahlian dari siswa.

\section{METODE PENELITIAN}

Penelitian yang digunakan untuk mengetahui elemen interaktivitas pada 
beban kognitif intrinsik dalam penelitian ini adalah penelitian kualitatif.Tujuan penelitian untuk menggali elemen interaktivitas yang muncul dalam pembelajaran matematika yang ada di SMK TELKOM Malang.Penelitian dilakukan pada kelas X RPL 3 Tahun pembelajaran 2015/2016.Penelitian ini bertujuan untuk mengetahui munculnya elemen interaktivitas pada pembelajaran matematika di SMK TELKOM Malang. Materi dalam pembelajaran matematika adalah Geometri pada SMK kelas X.

Instrumen utama sekaligus pengumpul data pada penelitian ini adalah peneliti sendiri. Peneliti mengamati proses pembelajaran matematika yang dilakukan oleh guru mata pelajaran matematika. Peneliti juga dibantu oleh 1 (satu) observer untuk mengamati pembelajaran yang sedang berlangsung sehingga ada pembanding antar peneliti dan observer.Penelitian berlangsung selama 3 pertemuan pembelajaran dengan materi geometri.

Lembar observasi, jurnal belajar siswa, pedoman wawancara, dan rekaman video pembelajaran merupakan instrumen pendukung dalam penelitian.Keempat instrumen tersebut sebagai alat untuk menggali munculnya elemen interaktivitas dalam pembelajaran matematika. Lembar observasi diisi oleh peneliti sebagai observer dan dibantu oleh 1 observer lain atau teman sejawat. Jurnal belajar diisi oleh siswa setelah pembelajaran selesai.Setiap akhir pembelajaran, peneliti memilih 6 siswa secara acak dan harus berbeda pada suatu pertemuan dengan pertemuan sebelumnya untuk diwawancarai.Melalui wawancara didapat data lebih mendalam tentang munculnya elemen interaktivitas yang dirasakan siswa pada saat pembelajaran.Peneliti juga merekam pembelajaran dari awal sampai akhir sehingga hasil rekaman dapat dianalisis kembali untuk melihat munculnya elemen interaktivitas dalam pembelajaran.

Penelitian diawali dengan persiapan yang terdiri dari menganalisis masalah, merancang instrument, memvalidasi instrument, dan observasi tempat penelitian.Persiapan yang dirasa sudah cukup maka, selanjutnya pengambilan data yang dilakukan di SMK TELKOM Malang.Pengambilan data dilakukan selama 3 pembelajaran Matematika.Data yang diperoleh kemudian dikelolah menggunakan teknik analisis data yang terdiri dari menstranskrip data verbal sampai penarikan kesimpulan. Untuk memastikan keabsahan data pada pengelolahan data maka dilakukan pemeriksaan keabsahan dengan 
caratriangulasi dan penyajian informasi berbeda (Creswell, 2014:286-288).

\section{HASIL DAN PEMBAHASAN}

Data yang diperoleh selama penelitian akan dibahas langsung berdasarkan elemen interaktivitas yang muncul pada pembelajaran matematika. Data berupa foto hasil kerja siswa, rekaman selama pembelajaran, jurnal belajar siswa, dan juga hasil wawancara. Pembahasan akan menjelaskan munculnya elemen interaktivitas yang ada dalam pembelajaran matematika.

Elemen Interaktivitas yang muncul terlihat dari rekaman pada saat pembelajaran (rekaman 0004 menit 1:10). Guru membahas tentang garis yang sejajar, perpotongan, dan bersilangan. Siswa memberikan jawaban yang salah ketika membahas soal.Ada beberapa siswa yang mengalami kesalahan dalam menjawab pertanyaan guru tentang garis yang sejajar, berpotongan, dan bersilangan. Kesalahan siswa dapat dilihat dari hasil wawancara:

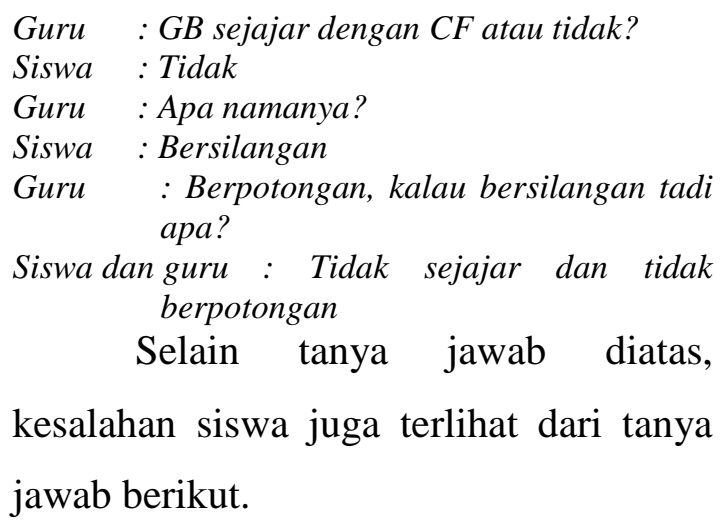
apa?

Siswa dan guru : Tidak sejajar dan tidak berpotongan

Selain tanya jawab diatas,

kesalahan siswa juga terlihat dari tanya jawab berikut.

$$
\begin{array}{ll}
\text { Guru } & \text { : BE dan CF apa namanya? } \\
\text { Siswa } & : \text { Sejajar } \\
\text { Guru } & : \text { Ndak, dia bersilangan } \\
& \text { Hasil lembar }
\end{array}
$$$$
\text { observasi }
$$

mengungkap

Elemen

Interaktivitasberasal dari garis yang berpotongan dengan yang bersilangan. Hasil jurnal belajar siswa juga terungkap bahwa siswa kurang bisa/kesulitan membayangkan kedudukan titik, garis, dan bidang. Kesulitan membayangkan lebih diperjelas lagi melalui hasil wawancara dengan siswa berinisial AIY yang mengatakan bahwa dalam belajar geometri tidak terlalu sulit tetapi yang sulit saat membayangkannya.
Peneliti : Menurut anda, apakah materi yang barusaja dipelajari sulit untuk dipahami? Mengapa anda merasa sulit memahami materi tersebut?
AIY : Ya gak sulit, Cuma susah bayanginnya

Elemen Interaktivitas yang muncul berikutnya adalah bidang yang sejajar.Siswa mengalami kesulitan dalam

\begin{tabular}{|c|c|}
\hline Guru & $\begin{array}{l}\text { : Sekarang, bidang yang } \\
\text { sejajar dengan BDG?, } \\
\text { kebayang apa tidak } \\
\text { bidang BDG? }\end{array}$ \\
\hline ebagain siswa & : Kebayang \\
\hline Sebagian siswa & $\begin{array}{l}\text { : Sebentar, sebentar, } \\
\text { bidang BDG } \quad \text { (sambil } \\
\text { membayangkan bidang } \\
\text { BDG pada gambar. }\end{array}$ \\
\hline Munculnya & Elemen Interaktivitas \\
\hline lat dari $\mathrm{k}$ & siswa \\
\hline $\mathrm{m} 1$ & \\
\hline $\mathrm{BD}$ & Interakti \\
\hline
\end{tabular}
membahas soal yaitu menentukan suatu bidang yang sejajar dengan bidang lainnya (rekaman 0004 menit 04:04). 
muncul dari kesulitan siswa dalam membayangkan bidang yang sejajar dengan bidang BDG. Kesulitan membayangkan ini terungkap dari hasil lembar observasi bahwa yang menjadi kesulitan siswa adalah membayangkan kedudukan titik, garis, dan bidang. Selain dari lembar observasi kesulitan membayangkan didukung oleh hasil jurnal belajar yang menjelaskan bahwa siswa kurang bisa membayangkan kedudukan titik, garis, dan bidang, kemudian diperjelas dengan hasil wawancara dengan siswa berinisial AIY.

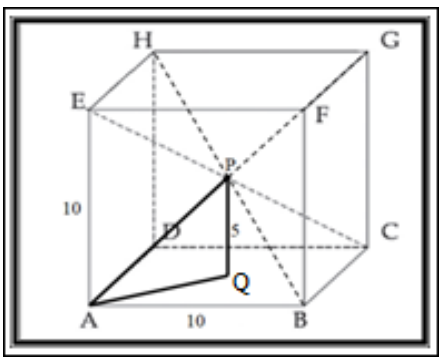

Gambar 1. Bangun Ruang Kubus Hasil Kerja Siswa

Dalam kegiatan pembelajaran muncul Elemen Interaktivitasyang dapat dilihat dari kesulitan yang dialami oleh siswa. Ada beberapa siswa yang sedikit mengalami kebingungan saat siswa yang mengerjakan di depan memberikan panjang 5 pada suatu garis. Karena ada beberapa siswa yang merasa kebingungan dengan panjang 5 pada pekerjaan siswa maka guru bertanya kepada siswa yang mengerjakan di depan.

Guru : La kok bisa

Siswa : ini kan sejajar dan sama dengan $C G$. Jadi ini ya setengahnya dari 10 pak.

Kesulitan siswa dalam memahami hasil kerja teman mereka disebabkan karena kurangnya kemampuan membayangkan kedudukan garis dalam bangun ruang. Kesulitan ini juga terungkap dari hasil jurnal belajar siswa bahwa mereka mengalami kesulitan dalam segi membayangkan kedudukan titik, garis, dan bidang. Kesulitan ini juga diperjelas dengan hasil wawancara dengan AIY yang merasa kesulitan dalam membayangkan kedudukan titik, garis, dan bidang dalam bangun ruang.

Dari hasil observasi terlihat Elemen Interaktivitas yang muncul adalah tentang perhitungan tentang kedudukan titik $\mathrm{P}$ dan panjang AQ yang bernilai $5 \sqrt{2}$. Siswa juga mengalami kesulitan saat guru membahas tentang panjang diagonal ruang yang bernilai $10 \sqrt{3}$. Elemen Interaktivitasjuga muncul pada saat siswa mengalami kesulitan dalam memahami bidang segitiga dalam bangun kubus. Kesulitan ini juga diperkuat dengan hasil wawancara dengan YIR sebagai berikut.

$\begin{array}{ll}\text { Peneliti } & \text { : Dimanakah letak kesulitan } \\ & \text { saudara dalam memahami } \\ & \text { materi? Mengapa dibagian } \\ & \text { tersebut anda merasa kesulitan } \\ & \text { dalam memahaminya? } \\ \text { YIR } & \text { :Ya kalau sudah masuk ke yang } \\ & \text { agak kompleks gitu, pada saat } \\ & \text { dipecah-pecah segitiga-segitiga, } \\ & \text { itu yang agak sulit. }\end{array}$


Pembahasan dilanjutkan dengan menghitung jarak titik A ke bidang BDE (rekaman 0009 menit 00:08). Pembahasan diawali dengan mengajak siswa untuk membayangkan bidang BDE pada bangun kubus.

$\begin{array}{ll}\text { Guru } & \text { : Bisa atau tidak } \\ & \text { membayangkan bidang BDE? } \\ \text { Siswa } & \text { : Bisa (Serentak) } \\ \text { Guru } & \text { : Apa jenis segitiga yang } \\ & \text { terbentuk? } \\ \text { Siswal } & \text { : Segitiga sama kaki } \\ \text { Siswa2 } & \text { : Segitiga sama sisi }\end{array}$

Dari percakapan di atas siswa mengalami kesulitan dalam membayangkan dan memahami panjang sisi-sisi pembentuk segitiga BDE.

Beban kognitif intrinsic disebabkan oleh jumah element yang harus diproses secara bersamaan dan keterkaitan antara unsur-unsur. Siswa kurang memahami topik materi pada pertemuan sebelumnya dapat mengakibatkan beban kognitif yang lebih berat pada pembelajaran topik materi yang sedang dipelajari. Pengetahuan sebelumnya dari siswa akan mempengaruhi tingkat kompleksitas materi yang dipelajari (Kalyuga, 2011:39). Topik materi yang sedang dipelajari berhubungan dengan topik materi yang dipelajari pada pertemuan sebelumnya.

Kesulitan siswa yang terjadi karena ada unsur dalam suatu topik materi yang tidak diproses. Siswa kurang memahami topik materi sehingga saat guru memberikan latihan soal, siswa mengalami kesulitan mengerjakan atau menjawab pertanyaan guru. Siswa tidak mengulang materi sebelumnya (mempelajari kembali) sehingga informasi yang ada dalam memori kerja terlupakan. Informasi dalam memori kerja hanya bisa bertahan beberapa menit dan jika tidak ada pengulangan akan dilupakan. Informasi sepenuhnya dipahami ketika semua element yang berinteraksi dapat diproses dalam memori kerja (Sweller, Ayres, dan Kalyuga, 2011:62). Siswa melupakan definisi dari dua garis yang berpotongan atau bersilangan sehingga siswa tidak dapat menjawab atau menentukan dua buah garis yang berpotongan atau bersilangan. Siswa kurang mampu melihat atau mengkonfigurasi, pengenalan bentuk dan kedudukan, dan merepresentasikan suatu titik, garis, atau bidang dalam bangun ruang (Gal dan Linchevski, 2010). Kesulitan yang dialami membuat siswa tidak bisa memahami kedudukan suatu titik, garis, dan bidang dalam bangun ruang. Dari situasi tersebut mengakibatkan munculnya beban kognitif intrinsic dalam praktik pembelajaran matematika.

\section{KESIMPULAN}

Elemen Interaktivitas merupakan bagian dari Beban kognitif intrinsic yang 
muncul dalam pembelajaran.Elemen Interaktivitas yang muncul dalam pembelajaran dapat terlihat dari kompleksitas materi yang sedang dipelajari sehingga siswa harus menghubungkan antara topik materi kedudukan titik, garis, bidang dan topik materi jarak dan besar sudut dalam bangun ruang. Kompleksitas materi yang sedang dipelajari juga melibatkan materi prasyarat seperti kesebangunan dua segitiga, aljabar, sudut istimewa dan keahlian siswa dalam belajar matematika.

\section{DAFTAR PUSTAKA}

Artino, A. R. J. (2008). Cognitive Load Theory and the role of learner experience: An Abbreviated Review for Education Practitioners. Association for the Advancement of Computing In Education Journal, 16(4): 425439

Cooper, G. (1998). Research into Cognitive Load Theory and Instructional Design at UNSW.(Online), (http://dwb4.unl.edu/Diss/Coope r/UNSW.htm), diakses 20 September 2015.

Creswell, J. W. (2009). Research Design: Pendekatan Kualitatif, Kuantitatif, dan Mixed, edisi-3. Terjemahan Achmad Fawai. 2014. Yogyakarta: Pustaka Pelajar
Gal, H. \& Linchevski, L. (2010). To See or not to see: Analyzing Difficulties in Geometry from the Perspective of Visual Perception. Educ Stud Math. 74:163-183

Kalyuga, S. (2011). Informing: A Cognitive Load Perspective.The International Journal of an Emerging Transdiscipline. 14:33-45

Peraturan Menteri Pendidikan Dan Kebudayaan Republik Indonesia Nomor 103 Tahun 2014 tentang Pembelajaran pada Pendidikan Dasar dan Pendidikan Menengah. (2014). Jakarta: Permendikbud.

Plass, L. J., Moreno, R. \& Brunken, R. 2010.cognitive Load Theory. New York: Cambridge University Press, (online).

Slavin, E. R. (2009).Psikologi Pendidikan: Teori dan Prakte, edisi-9. Terjemahan Marianto Samosir. 2011. Jakarta: Indeks

Subanji. (2015). Teori Kesalahan Konstruksi Konsep dan Pemecahan Masalah Matematika.Malang: Universitas Negeri Malang

Suyono \& Hariyanto. (2016). Belajar Dan Pembelajaran. Bandung: PT Remaja Rosdakarya

Sweller, J., Ayres, P. \& Kalyuga, S. 2011.cognitive Load Theory. New York: Cambridge University Press, (online).

Winkel, S, W. (2005). Psikologi Pengajaran. Yogyakarta: Media Abadi 